\title{
SURAU SEBAGAI PUSAT PENDIDIKAN ISLAM PADA MASA KESULTANAN PONTIANAK
}

\author{
MUHAMMAD RAHMATULLAH
}

Penulis adalah Dosen IAIN Pontianak

\begin{abstract}
ABSTRAK
Historically, the surau has become an important means (institution/agency) in terms of community development and enlightenment, particularly in religious learning and cultivation of moral values. In addition, the surau-based education had a significant reputation with regard to the spread of Islam to various regions and the area around an island and beyond, and probably to other countries.

As a means of religious education, we can still find surau until now, although its role and function are no longer the same as they were in the past, in which educational activities of Islam in the early days of its growth were carried out under the surau educational system. Thus, since the beginning of the spread of Islam to Indonesia, surau has contributed the shape and pattern of its own in the Islamic educational system
\end{abstract}

Key words: Surau, education, Islam, Sultanate Pontianak,

\section{PENDAHULUAN}

Kalimantan Barat, meskipun sejak lama tidak mempunyai Pesantren namun tempat-tempat belajar ilmu agama cukup banyak. Seperti di Kota Pontianak yang dikenal dengan Daerah Kerajaan atau Sultan, dahulu hampir di setiap kampung mempunyai orang 'Alim (Tuan Guru) yang puluhan tahun bermukim dan belajar Agama di Tanah Suci Makkah dan Madinah. Sebagai contoh, Tuan Guru H. Ismail Jabal ${ }^{1}$, Tuan Guru H. Abdul 'Aziz, Tuan Guru H. Muhammad Qasim, Tuan Guru H. Muhammad dan Tuan Guru H. Abdul Gani di Kampung Tambelan, Tuan Guru H. Usman di Kampung Kuantan (Parit Tokaya), Tuan Guru H. Abdurrahman bin H. Ismail dan Tuan Guru H. Husin di Kampung Kamboja, Tuan Guru Syarif (Saiyid) Ja'far

\footnotetext{
${ }^{1}$ Selama 50 tahun menetap di Makkah dan tinggal di Jabal Hindi, dan dikenal dengan nama H. Ismail Jabal.
}

Al-qadry di Kampung Melayu Laut, Tuan Guru H. Muhammad Arsyad di Kampung Segon. Para Tuan Guru tersebut melestarikan ilmunya dengan mengajar ilmu-ilmu agama di rumah dan Surau yang ada di setiap Kampung. Selain itu ada juga beberapa "Madrasah" yang menjadi pusat pendidikan pada masa itu. Jadi cukup banyak pada saat itu orang-orang 'Alim yang menguasai ilmu-ilmu Agama baik di Kerajaan Pontianak maupun di daerahdaerah lainnya, seperti Sambas ${ }^{2}$. (Mahmud, 1982: 2 - 4).

Kajian mengenai Surau sebagai institusi atau lembaga, bila dikaitkan dengan pendidikan agama Islam mempunyai beberapa arti penting: Pertama, surau merupakan institusi yang tidak bisa dikesampingkan, karena surau memainkan peranan yang sangat signifikan

\footnotetext{
${ }^{2}$ Daerah ini dulunya dikenal dengan "Serambi Mekkah" kemudian "Serambi Mesir".
} 
dalam menyebarkan ilmu-ilmu agama Islam jauh sebelum pendidikan berbasis madrasah muncul. Dalam sejarah tercatat, banyak tokoh-tokoh ulama "besar" yang mempunyai pengaruh luas lahir dari pendidikan di Surau. Mereka dididik dan dibesarkan di Surau. Demikian pula halnya dengan ulama dan Tuan Guru yang belajar dan mengajar di beberapa Surau pada Kerajaan Pontianak khususnya dan daerah lain di Kalimantan Barat Umumnya. Beberapa nama seumpama Tuan Guru H. Abdul Ghani (Datuk Haji Jelani) belajar kepada Tuan Guru Syekh H. Muhammad Arsyad Al-Banjari, pengarang Kitab Fiqh "Sabilal Muhtadin" yang berasal dari daerah Banjarmasin Kalimantan Selatan. Tuan Guru Ismail Jabal, misalnya adalah tokoh tarekat yang sebelumnya belajar fiqh dengan mufti dari keempat mazhab di Mekkah. H. Ismail Jabal menetap di Mekkah selama 50 tahun $(1870$ - 1919) kemudian kembali ke Pontianak. (Bruinessen, 1992: 120-121).

Kedua, semua surau yang dikenal pada masa lalu masa Kesultanan Pontianak sebagian besar sudah tidak ada lagi, seiring meninggalnya para Tuan Guru dan muridmuridnya. Surau-surau setelah Tuan Guru meninggal dunia, menjadi sepi dari pada pengajian dan pelajaran. Berbeda halnya dengan daerah Jawa, Sumatera, Sulawesi Selatan dan Kalimantan Selatan, khususnya Martapura. Bila seorang Kiyai/Ustadz/Tuan Guru meninggal dunia, banyak penggantinya. Akan tetapi Daerah Kalimantan Barat khususnya Pontianak tidaklah demikian keadaannya. Ulama dan Tuan Guru yang telah wafat, kalaupun ada penggantinya tidak seimbang dengan hajat ummat Islam, baik kualitas maupun kuantitas. Sehingga mengkaji Surau dan peran Tuan Guru pada masanya menjadi sesuatu yang penting untuk dicatat dan dibahas sebagai sumber sejarah untuk daerah Kalimantan Barat.

Ketiga, menurut penulis, sumber primer yang didapatkan penulis belum pernah ditulis dan dipublikasikan, sehingga sumber data yang ada ini menjadi yang penting untuk dipublikasikan agar pembaca dapat mengetahui dan mempelajari berbagai informasi dan keterangan yang diperoleh dalam sumber yang ada. Mungkin saja berbagai data yang ada dapat menjadi sumber sejarah pendidikan agama Islam pada awal abad XII Hijriyah dan awal abad XVIII Masehi di daerah Pontianak Kalimantan Barat.

Makalah ini hendak melihat seberapa jauh peran dan fungsi surau pada masa Kesultanan Pontianak. Bagaimana peran para Tuan Guru dalam melaksanakan pempelajaran agama Islam pada tiap-tiap Surau. Selain itu penulis ingin memaparkan salah seorang Tokoh Ulama Kalimantan Barat, yang telah dididik dan diajar oleh beberapa Tuan Guru, meskipun beliau bukan hasil didikan pondok pesantren, akan tetapi ilmu dan pengetahuannya sebanding dengan Ulama dan Kiyai yang berasal dari Pondok Pesantren di daerah Jawa.

Secara metodologis penulisan
makalah ini mengambil bentuk
pendekatan-pendekatan yang bersifat historis dan sosiologis. Perbincangan dan pembahasan dilakukan dengan melihat dan menggali ke dasar sejarah dan kembali melihat realitas yang ada. Berbagai informasi dan analisa yang ditulis dalam tulisan ini bersifat deskriptif, karena sejalan dengan tujuan dari tulisan ini yakni mengungkapkan apa yang ditulis sesuai dengan kondisi atau keadaan yang sebenarnya.

\section{PENGERTIAN SURAU}

Surau, istilah Melayu-Indonesia "surau" dan kontraksinya "suro" adalah kata yang luas pengunaannya di Asia Tenggara. Sejak waktu yang sangat lama, dalam pengertian yang sama, istilah ini banyak digunakan di Minangkabau, Sumatera Selatan, Semenanjung Malaysia, Sumatera Tengah dan Patani (Thailand 
Selatan). Secara bahasa surau berarti "tempat" atau "tempat penyembahan". Menurut pengertian asalnya, surau adalah bangunan kecil yang didirikan untuk penyembahan arwah nenek moyang. Dengan datangnya Islam, surau juga mengalami proses Islamisasi, tanpa harus menagalami perubahan nama. (Azra,2012 : 150).

Dalam Kamus Umum Bahasa Indonesia susunan WJS. Poerwadarminta, Surau diartikan sebagai tempat sembahyang (shalat), mengaji dan langgar. Sedangkan Gerard Moussay dalam Dictionnaire Minangkabau Indonesien menyebutkan bahwa surau ialah tempat belajar Agama; surau digunakan juga sebagai asrama bagi remaja yang mulai tumbuh dewasa. Dalam Ensiklopedi Pendidikan yang ditulis oleh Soegarda Poerbakawatja, dkk, disebutkan bahwa surau merupakan tempat belajar di Sumatera Barat. Di surau diberikan pelajaran keagamaan ${ }^{3}$.

\section{KEGIATAN ULAMA/TUAN GURU DAN FUNGSI SURAU}

Menurut Azyumardi (2012:151), di Malaysia terdapat perbedaan fungsi antara surau dan masjid. Khusus di Kelantan, misalnya surau adalah pusat ritual Islam pedesaan; tempat shalat jumat dan kegiatan keagamaan lainnya, termasuk pendidikan. Di Malaysia terdapat surau besar dana surau kecil. Surau besar tampaknya sama fungsinya dengan masjid di Indonesia. Sebaliknya surau kecil biasanya digunakan sebagai tempat memberikan pelajaran dasar agama, seperti membaca Al-Qur'an, pengetahuan tentang rukun iman, rukun Islam, cara melaksanakan ibadah-ibadah

\footnotetext{
${ }^{3}$ Tulisan ini dikutip dari Penelitian Kelompok penulis pada PUSLIT IAIN Padang, 2010 A. Surau dalam Sejarah Pendidikan Islam di Minangkabau, diakses pada hari Senin tanggal 2 Juni 2014 di http://surautuo.blogspot.com/2011/03/suraumelirik-aktifitas-transmisi.html
}

pokok. Dalam fungsi ini, surau sama kedudukannya dengan langgar di Jawa. Di Indonesia, surau seperti juga masjid umumnya dikelola masyarakat, baik dari segi dana pembangunan dan pengembangannya. Adapun di Malaysia, ia dikelola kerajaan melalui Majelis Ulama dan Isti'adat Melayu; untuk tujuan administrative, di Malaysia diadakan pembedaan antara surau besar dan surau kecil.

Surau sebelum kedatangan Islam, di Minangkabau mempunyai kedudukan penting dalam struktur kehidupan masyarakat. Fungsinya lebih daripada sekedar tempat kegiatan keagamaan. Menurut ketentuan adat, surau berfungsi sebagai tempat berkumpul para remaja maupun laki-laki dewasa yang belum kawin atau duda. Karena adat menentukan, laki-laki tidak memiliki kamar di rumah orang tua mereka, mereka bermalam di surau. Kenyataan semacam inilah membuat surau menjadi amat penting bagi sosialisasi dan pendewasaan generasi muda Minangkabau, baik dilihat dari sisi ilmu pengetahuan maupun keterampilan praktis. (Azra, 2012 : 151-152).

Menurut Azyumardi Azra (2012 : 152), fungsi surau tidak juga berubah setelah kedatangan Islam. Hanya saja fungsi keagamaan semakin penting. Awalnya surau menjadi tempat memperoleh pengetahuan dasar keagamaan. Surau sebagai lembaga pendidikan Islam selengkapnya pertama kali dikembangkan oleh Syekh Burhanuddin di Ulakan, Pariaman setelah ia kembali dari Aceh. ${ }^{4}$ Syekh Burhanuddin terkenal karena kedalaman ilmu dan kesalehannya, suraunya dapat menarik banyak murid di Minangkabau. Murid-muridnya yang berperan besar dalam mengembangkan surau sebagai lembaga pendidikan adalah empat orang Tuanku, yang terkenal dengan sebutan Urang Ampek Angkek. Surau pada

\footnotetext{
${ }^{4}$ Tempat ia belajar dengan Syekh Abdurrauf alSingkili.
} 
masa ini berfungsi juga sebagai pusat Tarekat, terutama Syattariyah. Selain itu terdapat surau-surau yang menganut Tarekat Naqsyabandiyah.

Berbeda halnya dengan daerah lainnya, fungsi surau di Kesultanan Pontianak Kalimantan Barat, hanya semata-mata sebagai tempat belajar dan mengajar ilmu agama Islam. Meskipun di daerah kerajaan atau kesultanan Pontianak tidak terdapat pesantren, tetapi dulu hampir disetiap kampung ada orang 'Alim (Tuan Guru) yang telah puluhan atau lebih dari 5 (lima) tahun bermukim dan belajar di Tanah Suci Mekkah, yakni di Masjidil Haram dan di Madinah, Masjid Nabawiy.

Menurut orang-orang tua; Pada permulaan abad XII Hijriyah di Kampung Kuantan terdapat seorang Tokoh Ulama Tuan Guru H. Usman namanya. Beliau mengajar di Surau yang terletak di pinggir Parit Tok Kaya. Setelah beliau meninggal, datanglah Tuan Guru H. Abdullah ${ }^{5}$ untuk menggantikannya mengajar di Surau Parit Tok Kaya. Sebelum Tuan Guru H. Abdullah pulang dan menetap di Pontianak, telah datang pula seorang 'Alim $\mathrm{H}$. Muhammad Ali. Beliau datang dari daerah Banjarmasin, menetap di Kampung Kamboja dan mengajar di Surau Haji Mustafa. Di sebelah hilir surau ini, terdapat sebuah surau yang dahulu dikenal dengan nama Surau Tuan Guru H. Muhammad Bakau $^{6}$. Beliau terkenal sebagai Alim Tokoh Ulama Ahli Qiraat Tujuh dan sebagainya. Pendirian dan sikap beliau amat keras. Selain Tuan Guru $H$. Muhammad ada 2 (dua) orang Tuan Guru yang menetap di Kampung Kamboja, yaitu Tuan Guru H. Abdurrahman bin H. Ismail ${ }^{7}$ dan Tuan Guru H. Husin,

\footnotetext{
${ }^{5}$ Beliau dikenal sebagai Tokoh Ulama yang telah puluhan tahun muqim dan belajar di Tanah Suci, bahkan ia menjadi salah seorang tokoh Syuriyah "Syarikat Islam".

${ }^{6}$ Sebenarnya nama beliau H. Muhammad bin H. M. Said.

${ }^{7}$ Beliau adalah seorang tokoh Ulama yang paling keras sikap dan pendiriannya, pernah muqim dan
}

penterjemah kitab "Tuhfatur Raaghibiyn". 8 (Mahmud, 1982: 3)

Selain surau-surau di atas, terdapat sebuah Surau di kampung Melayu Laut, bernama Surau Wan (Saiyid) Qasim Baraqabah ${ }^{9}$, dan di surau ini pernah mengajar Tuan Syarif (Saiyid) Ja'far AlQadry. ${ }^{10}$ Satu-satunya murid beliau yang tenar namanya di kalangan Qurra' adalah Syekh Muhammad Asy-Syarwaniy. 11 Kemudian beliau (Tuan Syekh Muhammad Syarwaniy) terkenal dengan gelaran "Kerajaan Pangeran Negara".

Pada tahun 1911 di Kampung Tambelan, Surau "Khusnul Khatimah" yang dulu dikenal dengan Surau Tuan Guru H. Abdul 'Aziz." ${ }^{12}$ Tidak jauh dari surau tersebut terdapat sebuah surau lagi, berada di sebelah hulu Surau "Nahdhatusy Syakirin". Tuan Guru H. Muhammad Qasim mengajar di surau ini, setelah pulang dari muqim dan belajar di Tanah Suci, kembali menetap di Kampung kelahirannya. Beliau mengajarkan ilmu Nahwu, Sharaf dll. Setelah Tuan Guru Abdul Aziz wafat kira-kira tahun 1917, kembali ke Pontianak Tuan Guru H. Muhammad bin $H$. Abdullah setelah meneruskan belajar di Mekkah selama

\footnotetext{
belajar di Tanah Suci puluhan tahun, beliau adalah Mursyid Thariqat Naqsyabandiyah.

${ }^{8}$ Konon kabarnya , Beliau terkenal pula sebagai ahli lagu-lagu Qashidah Arab.

${ }^{9}$ Ayahanda Wan (Saiyid) Husin Khatib Masjid Sulthan Pontianak.

${ }^{10}$ Beliau adalah Mursyid Thariqat Naqsyabandiyah. Beliau juga dikenal sebagai ahli Tajwid dan Qiraat.

11 Putera Syekh Mahmud Asy-Syarwaniy putera Syekh Abdul Hamid Al-Syarwaniy, pengerang Kitab Hasyiyah Tuhfah.

12 Meskipun beliau adalah Mursyid Tariqat Naqsyabandiyah, beliau juga memberikan pelajaran-pelajaran Agama Islam dan Ilmu-ilmu Nahwu, Sharf dan lain-lain. Beliau terkenal sangat wara', sangat jarang keluar rumah kecuali ke surau untuk shalat dan ke Masjid Jami' Sulthan untuk shalat Jum'at dan Hari Raya Idul Fithri serta Idul Adha.
} 
lebih kurang 10 tahun lamanya. ${ }^{13}$ Beliau belajar di Tanah Suci setelah lebih dahulu belajar di Pontianak kepada Tuan Guru Muhammad Ali, Tuan Guru H. Abdullah (Kamboja - Kuantan) dan Tuan Guru H. Abdul Aziz Kampung Tambelan. Setelah pulang dari Makkah, Tuan H. Muhammad, tidak langsung pulang ke Pontianak, tetapi singgah dan berdiam sebentar di Betawi (Jakarta). Di Surau Tuan Guru H. Abdul Aziz, Tuan Guru H. Muhammad dengan tekun mengajar dan kadang-kadang di rumah beliau. Beliau mengajar dari pagi jam 08.00 - jam.12.00. Setelah shalat Asar sampai jam 17.30 dekat maghrib. Dan Setelah selesai shalat Isya sampai jam 22.00 atau jam 23.00 malam, kecuali Jum'at dan Bulan Ramadhan istirahat. (Mahmud, $1982: 3-4$ )

Pada tahun 1919, Tuan Guru H. Ismail Jabal ${ }^{14}$ kembali dan menetap di kampung kelahirannya Kampung Tambelan. Beliau telah bermuqim di Makkah selama 50 tahun, yaitu di Jabal Hindi. Lebih kurang 30 tahun, beliau belajar kepada Ulama diantaranya Muftimufti dan Tokoh-tokoh Ulama dari Empat Mazhab, seperti Maulana Saiyid Abdullah bin Muhammad Saleh Az-Zawawiy AlHasani Mufti Mazhab Imam Syafi'i.

13 Beliau belajar kepada beberapa Ulama Terkemuka antara lain : Syekh Ahmad Khatib bin Abdullatif Al-Minangkabawy (5 tahun) dan Syekh Khalifah bin Hamdun An-Nabhaniy Al-Bahrainiy Al-Makkiy.; kedua tokoh ini adalah Ahli Hisab. Tajwid, beliau pelajari dari Syekh Abdulhaq AlHindy. Selain itu beliau juga belajar kepada $H$. Syekh Usman bin Abdul Wahhab Syihabuddin Sarawak (selama 5 tahun), Syekh Umar Bali (1 tahun), Syekh Abdul Malik bin Syekh Ahmad Khatib Abdul Ghafar As-Sambasiy; penghimpunThariqat Qadiriyah wan Naqsyabandiyah (5 tahun). Beliau belajar Kitabkitab selama 23 tahun, sejak umur 7 tahun hingga umur 30 tahun.

14 Beliau pergi ke Makkah melalui Singapura memakai perahu layar dari Pontianak oleh orang tuanya Haji Abdullathif ketika berumur 10 tahun (lahir kira-kira tahun 1859 M., jadi ke Makkah tahun 1869 M). Dari Singapura menumpang kapal layar Inggris ke Mekkah.
Ketika di Makkah Tuan Guru Ismail Jabal diserahkan kepada Tuan Syekh Usman ${ }^{15}$ bin Abdul Wahab Syihabuddin (ketika itu berumur kira-kira 25 tahun). Kembalinya Tuan Guru H. Ismail Jabal disambut dengan penuh gembira, kasih saying dan sangat dihormati, baik oleh Sulthan Syarif Muhammad Al-Qadriy, Pangeran-pangeran, Alim Ulama apakan lagi rakyat yang terdiri dari ummat Islam. Tuan Guru Ismail Jabal mengajar di rumah Beliau, sebuah rumah yang besar sekali ketika itu. Setelah 2 (dua) tahun kemudian, datang pula seorang 'Alim, kelahiran negeri Kelantan, yaitu Tuan Guru H. Ismail Kelantan ${ }^{16}$, yang lama pula muqim dan belajar di Tanah Suci. Beliaupun diterima oleh Sulthan dan rakyat. Karena lincah dan tangkas, maka jabatan Mufti Kerajaan Pontianak diserahkan kepada beliau dan selanjutnya dikenal sebagai Tuan Guru H. Ismail Mufti. Sulthan sebagai Hakim Mahkamah Syari'ah (Raad Agama) maupun Mufti dalam melaksanakan tugastugas mereka, tidak pernah "meninggalkan" pertimbangan dan pendapat Tuan Guru H. Ismail Jabal. Maka Tuan Guru H. Ismail Jabal mendapat kehormatan dengan sebutan Tuan Guru H. Ismail Qadhiy, meskipun beliau tidak menyandang jabatan tersebut.(Mahmud,

\footnotetext{
${ }^{15}$ Syekh Usman ini lahir di Sarawak, ketika masih kecil dibawa pindah ke Pontianak, tinggal di Kapung Tambelan. Setelah hamper dewasa dibawa orang tuanya ke Tanah Suci, beliau tinggal dan belajar disana. Syekh Usman ini adalah perterjemah kitab-kitab Tashawwuf, antara lain "Tanwirul Qulub" = Penerang Sekalian Hati”, dll. Sebagai pengarang dan penterjemah, beliau menulis namanya "Syekh Usman bin Syihabuddin Pontianak" lebih banyak dari pada "Syekh Usman bin Syihabuddin Serawak". Di kalangan orangorang tua dahulu ada yang mengatakan bahwa Ibu syekh ini orang Sarawak dan ayahnya orang Pontianak, da nada pula yang mengatakan sebaliknya.

16 Beliau adalah salah seorang murid Saiyid Abdullah Az-Zawawiy Al-Hasany. Beliau lebih banyak mengajar di Sungai Itik Kecamatan Sungai Kakap, dahulu dalam wilayah Sulthan Pontianak.
} 
1982:4-5).

Tahun 1923, Tuan Guru H. Muhammad Qasim dijemput orang pulau Jemaja untuk mengajar disana. Belum sampai 1 (satu) tahun beliau wafat di pulau Jemaja. Setelah Surau tempat Tuan Guru H. Muhammad Qasim di Kampung Tambelan lowong, maka Tuan Guru H. Ismail Jabal memberikan pengajian. Tuan Guru $\mathrm{H}$. Ismail Jabal berhenti mengajar dan mohon kepada Tuanku Sulthan Syarif Muhammad Al-Qadry untuk meletakkan jabatan selaku Anggota Penasehat Mahkamah Syari'ah (Raad Agama) Kerajaan Pontianak, kirakira permulaan tahun $1355 \mathrm{H}=1938 \mathrm{M}$. Beliau wafat pada hari Ahad (Minggu) 22 Dzilhijjah $1357 \mathrm{H}$, bersamaan 28 Pebruari 1938 M, mencapai usia 79 tahun Syamsiyah dan 83 tahun Qamariyah. Shalat Janazah beliau diimami oleh Tuan Guru H. Muhammad, penganti beliau di Mahkamah Syari'ah (Raad Agama) dan dihadiri Tuanku Sulthan. Makamnya di Perkuburan Keluarga di Kampung Tambelan. Tuan Guru H. Muhammad menghentikan mengajar karena sering sakit dan pemandangan beliau menjadi suram pada tahu 1950. Dan Tuan Guru H. Muhammad meninggal dunia di Tasikmalaya pada tahun 1958, setelah hijrah ke Jakarta tahun 1952 untuk berobat.

Di sebelah Hulu Surau H. Ismail Jabal, terdapat sebuah Surau yang terkenal dengan nama Surau Tuan Guru H. Abdul Ghani di Kampung Tambelan. Di Tanah Suci, Tuan Guru H. Abdul Ghani mengambil "jurusan" Ilmu Tashawwuf dan Thibbul Hikmah; cara pengobatan menurut Tradisi Arab Maghribiy. Beliau Wafat tahun $1354 \mathrm{H}=$ tahun $1936 \mathrm{M}$.

Di Kampung Sampit, terdapat pula sebuah Surau yang terkenal dengan nama Surau H. Mahmud (didirikan oleh Tuan Guru H. Abdul Ghani yang lebih dikenal dengan nama Datuk H. Jelani). Tuan Guru H. Abdul Ghani lahir tahun 1200 H., masih dalam pemerintahan Sulthan Syarif Abdurrahman (w.1223 H). Beliau pergi ke
Banjar tahun 1218 H., belajar kepada Tuan Guru Syekh Muhammad Arsyad AlBanjari pengarang Kitab "Sabilal Muhtadiyn" selama 9 tahun. Bukan hanya Ilmu Agama dengan Nahwu, sharf dan sebagainya, bahkan ilmu bela diri dan ilmu "gagah"pun beliau pelajari. Tuan Syekh itu wafat tahu 1227 H. Setahun kemudian, beliau pulang ke Pontianak, yaitu tahun $1228 \mathrm{H}$, dan pada tahun $1229 \mathrm{H}$. beliau mendirikan Surau tersebut yaitu Surau H. Mahmud/ Surau Datuk H. Jelani. Di Surau itulah beliau duduk mengajar. Muridmuridnya bukan saja dari penduduk Pontianak sendiri, bahkan juga dari negerinegeri di sekitar Pontianak. Sampai beliau wafat tahun $1300 \mathrm{H}$. Dalam usia 100 tahun Qamariyah, dan beliau mengajar lebih kurang 72 tahun. Selanjutnya Tuan Guru h. Abdul Ghani digantikan puteranya mengajar di Surau itu, yaitu Tuan Guru H. Muhammad Saleh, yang wafat tahun 1310 $\mathrm{H}$.

Kira-kira tahun 1317 H. datang seorang 'Alim dari Sarawak, pernah belajar di Tanah Suci selama 10 tahun, yaitu Tuan Guru H. Muhammad Saleh bin H. Muhammad Yusuf (lahir 1285 H.) tiba di Pontianak, lalu Beliau diminta dan mengajar di surau "Datuk H. Jelani", setelah surau tersebut dipugar. Setelah 5 tahun mengajar (th. 1322 H.), salah seorang murid beliau yaitu $\mathrm{H}$. Thaha pergi meneruskan pelajarannya ke Negeri Kelantan (Malaysia). Tahun 1323, Tuan Guru H. Muhammad Saleh merantau ke pedalaman Sungai Kapuas sampai Selimbau, kemudian Ketapang dan Sukadana, selanjutnya ke Sambas dan setelah itu ke Mempawah, Sungai Bundung sampai wafat pada hari Selasa 27 Syawal 1363 H. Setelah itu untuk mengisi kekosongan Surau, H. Muhammad Arsyad memberikan pengajian. Beliau sempat juga belajar kepada Syekh Mahmud AsySyarwaniy, putera syekh Abdul Hamid Asy-Syarwaniy (Pengarang Kitab Hasyiyah Tuhfah), ayahanda Pangeran 
Negara Syekh Muhammad Asy-Syarwaniy. Pernah belajar kepada Saiyid Abdullah AzZawawiy ketika menjadi Mufti Kerajaan Pontianak. Kemudian kepada Saiyid Ja'far Al-Muthahhar.

Tuan Guru H. Thaha, kembali dari Kelantan pada tahun $1330 \mathrm{H}$. setelah belajar disana selama 8 tahun. Beliau mengajar di Surau Datuk H. Jelani. Kemudian beliau mendirikan Surau di Kampung Serasan (Banjar Serasan). Tuan Guru H. Thaha dijemput Utusan Panembahan Sanggau Muhammad Tahir Surya Negara, untuk sekian kalinya mengajar di Sanggau. Setelah lebih kurang 3 (tiga) bulan beliau mengajar disana, beliau mendapat sakit dan segera pulang ke kampung Serasan Pontianak. Kemudian beliau wafat pada tahun $1347 \mathrm{H}$.

Pada tahun 1345 H. Tuan Guru H. Muhammad Arsyad Kampung Segon membangun sebuah Surau di Kampung Serasan, di sebelah Hulu Surau Tuan Guru H. Thaha, untuk memenuhi hajat masyarakat disitu. Tuan Guru $H$. Muhammad Arsyad mengajar di Surau tersebut. Beliau mengajrakan cara memperindah bacaan Al-Qur'an selain pelajaran shalat dan sebagainya. Beliau adalah ahli Tilawah dan Tajwid. Di Tahan Suci, beliau langsung belajar kepada salah seorang Ulama Besar, Tuan Syekh Abdullah Pengarang Kitab Tajwid "Mawriduzhzham An" pada Masa "Sarikat Islam", periode $\mathrm{H}$. Ismail $\mathrm{H}$. Umar Ketua Tanfidziyah, dan beliau adalah Sekretaris.

\section{TOKOH ULAMA KALIMANTAN BARAT YANG LAHIR DARI PENDIDIKAN SURAU}

H. Abdul Rani Mahmud ${ }^{17}$ salah seorang murid yang belajar dengan beberapa Tuan Guru yang hidup pada masa mudanya, seperti Tuan Guru $\mathrm{H}$.

\footnotetext{
${ }^{17}$ Dikenal juga dengan Nama Syekh H. Abdul Rani Mahmud Al-Yamani setelah pulang dari Tanah Suci Mekkah untuk melaksanakan Haji yang Pertama.
}

Thaha Kampung Banjar Serasan, Tuan Guru H. Ismail Jabal, Tuan Guru Haji Muhammad binH. Abdullah dan Tuan Guru H. Abdul Rani semua di Kampung Tambelan. Beliau belajar Ilmu Agama di Madrasah dan Surau. Setelah belajar lebih kurang 27 tahun, beliau mengajar di beberapa tempat.

H. Abdul Rani Mahmud adalah sosok Ulama yang terkemuka di Kalimantan Barat. Beliau menguasai disiplin ilmu Agama Islam $^{18}$. Selain di bidang Agama ia juga menyenangi kesenian yang bernafaskan Islam. 19 Sebagai seorang Ulama popularitas beliau sangat diakui oleh masyarakat Kalimantan Barat. Banyak karya-karya beliau $^{20}$ yang belum sempat dibukukan dan diketahui oleh masyarakat luas dan umumnya.

Masa pendidikan H. Abdul Rani Mahmud dimulai dengan pelajaran dasar membaca Al-Qur'an yang didapatnya dari orang tuanya sendiri dan datuknya, H. Muhammad Arsyad dan neneknya, setelah itu belajar kepada seorang Tuan Guru Ahmad di Kampung Kuantan dan tamat (khatam) 15 Sya'ban 1337 H. Kemudian dilanjutkan dengan belajar baca-tulis Melayu huruf Arab ${ }^{21}$ juga diajar oleh ayah dan datuknya. Hal ini berlangsung selama lebih kurang empat tahun, yaitu sejak ia berusia 6 tahun sampai 10 tahun (antara tahun 1918 sampai 1922). Ia belajar berbagai disiplin ilmu dengan berbagai kitab ${ }^{22}$

\footnotetext{
18 Ilmu Syar'iyah (Ilmu Fiqh, Ilmu Tafsir, Ilmu Hadits), Ilmu Adab (ilmu alat yang empat belas), Ilmu Riyadhah (Ilmu Tasawuf, Ilmu Politik dan Strategi, Ilmu Akhlak dll.), Ilmu "Ciptaan" akal saja (Ilmu Manthiq/logika, ilmu Ushul Fiqh, Ilmu Ushuluddin, Ilmu Ketuhanan/Theologie, ilmu Miqat/mengenai awal dan akhir bulan, Gerhana, Qiblat, dsb.)

${ }^{19}$ Seperti Hadrah, Jepin dan Gambus.

${ }^{20}$ Karya-karya tulis; baik berupa buku diktat, makalah maupun tulisan-tulisan lainnya.

${ }^{21}$ Dikenal dengan nama "tulisan Arab Melayu".

${ }^{22}$ Kitab yang dipelajari dari pamannya itu antara lain : "Tuhfah Al-Athfaal" (Ilmu Tajwid), "Umm
} 
kepada pamannya Muhammad Makkah dari tahun 1338 H. sampai dengan 1345 H.

Pendidikan yang ditempuh selanjutnya adalah Sekolah Gubernemen di Pontianak selama 5 tahun (tahun 1923 - 1928), dan tamat dengan sertifikat. Ia sekolah Gubernemen pada pagi hari dan sore harinya ia masih tetap melanjutkan pelajarannya yaitu Pengajian Al-qur'an dan pelajaran Agama Islam. Malam hari ia gunakan waktunya untuk belajar Seni budaya Islam. (Mahmud 1984:1). Sehingga tidak heran kalau ia sangat mahir sekali dalam "Seni Budaya Islam" yang telah dipelajarinya.

H. Abdul Rani Mahmud menggunakan sebagian besar waktunya untuk belajar dari pagi, sore hingga malam hari. Ia sangat haus akan ilmu; baik ilmu agama Islam maupun lainnya. Pada usia 17 tahun beliau belajar Kitabkitab yang berbahasa Arab seperti Ilmu Bahasa Arab (Nahwu, Sharf, Ma'ani, Bayan, Badi' dan sebagainya), Tauhid, Mantiq, Fiqh dan Tasawuf. Ia belajar pada pagi, sore dan malam hari di Surau-surau Tuan guru yang hidup pada masa itu (tahun 1929 - 1936). Ia belajar Ilmu-ilmu di atas pada Tuan Guru H. Thaha ${ }^{23}$ di Kampung Banjar Serasan, Tuan Guru H. Ismail Jabal ${ }^{24}$, Tuan Guru

Barahiin" (Ushuluddin), "Safinah Al-Shalah", Safinah Al-Najah" "Al-Ghayah wa Al-Taqriib" (Fiqh), "Dham”, “Al-'Awam li Al-Jurjaniy (Bahasa Arab).

${ }^{23}$ H. Abdul Rani belajar padanya ilmu Nahwu dan Sharf. Adapun kitab-kitab yang dipelajarinya antara lain : "Mukhtashar Jiddan", "Kafrawiy”, "Syekh Khalid", "Kawakib" dan "Qathar Al-Nada" , "Majmuah Al-Sharf", "Al-Bina”,, Syarah "AlMaqsud”, Al-Kailaniy”, "Wisyah Al-Afrah”, ia belajar kitab-kitab tersebut dari tahun $1342 \mathrm{H}$ sampai dengan $1347 \mathrm{H}$.

${ }^{24}$ Kitab-kitab yang dipelajarinya antara lain : "Fath Al-Qarib" dengan Hasyiyah "Al-Bajuriy", "Fath Al-Muin" dengan Hasyiyah "I'anah Al-Thalibiin”, Hasyiyah "Tuhfah”, Syarah "Hikam”.
H. Muhammad ${ }^{25}$ dan Tuan Guru H. Abdul Rani ${ }^{26}$ di Kampung Tambelan Pontianak. (Mahmud 1984 : 1).

Selain belajar ia juga sudah mulai mengajar, yaitu mengajar anak-anak membaca Al-Quran beserta Tajwid, Qiraat Tujuh, belajar mengaji Kitab; diantaranya : Irsyadul Anam, Muniyatul Mushally. Seni Budaya Islam; Nazham, Diba', Tala' $a l .{ }^{27}$

Selanjutnya pada tahun 1937 beliau belajar di Madrasah Al-Raudatul Islamiyah (Al-Qismun Nihaiy) Jalan Merdeka Barat Pontianak. Disana beliau belajar Tafsir dengan ushulnya, UlumulQur'an, Hadits dengan Mutsthalahnya, Tarikh, Ushul Fiqh, Nahwu, Sharf, Mantiq, Hisab, Miqat, Falaq dan lain-lain, hingga ia tamat pada tahun $1945^{28}$. Sore hari ia meneruskan

${ }^{25}$ Ia juga belajar Nahwu, Sharaf, Balaghah, Tajwid dan Ilmu Hisab; hisab 'Urfiy dan Taqwiem serta hisab Haqiqy. Kitab-kitab yang telah dipelajarinya antara lain : "Rubu' Mujaiyab", "Al-Minah AlFikriyah 'ala Jazaziyah", "Tajan Al-Durariy", "Syarkawiy", "kifayah Al-Awam","Fath AlWahab", Syarah "Hikam", "Ihya' 'Ulum AlDiin".

${ }^{26}$ Kitab-kitab yang dipelajari dari Tuan Guru ini yaitu : "Bidayah Al-Hidaayah", "Al-Tanwiir $f i$ Isqaat Al-Tadbir (Tasawuf), "Syams Al-Ma'arif AlKubra" "Khazinah Al-Asrar" (Ilmu Pengobatan/Thib).

27 Seperti yang diinformasikan oleh M. Saleh Thayeb; salah seorang anak yang diajarnya pada masa itu

28 Kitab-kitab yang telah dipelajarinya di Madrasah Al-Raudhatul Islamiyah, antara lain: "Fath Al-Mughits", "Al-Baiquniyah”, "Nuzhah Nazhar"dan "Raf Al-Astar" (kitab-kitab Hadits), "Nahj Taisir fi 'Ulum Al-Tafsir", "Itmam Al-Dirayah" dan "Al-Itqan" (Tafsir dan Ulumul Qur'an), "Alfiah”, Hasyiyah "Fath Al-Jalil" dan "Al-Jawahir Al-Balaghah" (Nahwu, Sharf dan Balaghah), "al-Majmu", Syarah "Al-Muhadzdzab", "Fath Al-'Aziiz" Syarah "Al-Wajiiz”, “Al-Talkhish Al-Kabir”, "Al-Mizan", "Rahmah Al-Ummah”, "Bidayah Al-Mujtahid”, "Madkhal Al-Washul”, "Lathaif Al-Isyarah", "Al-Mudzakkirat”, dan "Jami' AlJawami"” (Fiqh dan Ushul Fiqh), "Al-Tuhfah Al-Tsaniyah", "Al-Rahbiyah", Syarah "Sabth Al-Maardiniy”, Hasyiyah “Al-Baqariy”, Syarah 
pelajarannya di Madrasah tersebut dan pada malam harinya ia tetap meneruskan pengajian di Surau-Surau. dan masih sempat mengikuti Kursus-kursus Kepemimpinan.

Dan pada masa tuanya ia lebih menekuni bidang Tareqat. Menurut Hawash Abdullah $^{29}$ (1983 : 182), Ia juga mengembangkan amalan Tareqat yang diterimanya dari Tuan Gurunya Ismail Jabal $^{30}$ dan dari kakeknya sendiri yang telah menerima dari Syaikh 'Abd AlLatif bin H. Abdul Qadir Al-Sarawaki, yaitu Tareqat Qadariryah dan Tareqat Naqsyabandiyah, yang pada akhirnya ia berafiliasi dengan Abah Anom, Syaikh Qadiriyah Wa Naqsyabandiyah yang berpengaruh dari Suryalaya, dan Tasikmalaya. Dan ia diberi Ijazah menjadi satu-satunya guru Qadiriyah wa Naqsyabandiyah yang berpengaruh di Kalimantan Barat ${ }^{31}$ dan menjadi "Wakil Tunggal" Abah Anom di Kalimantan Barat. (Bruinessen 1992 : 122-123). Kini H. Abdul Rani Mahmud telah wafat ${ }^{32}$, namun pengganti atau penerusnya yang

"Syamsyuriyah" dan Hasyiyah Al-Bajuriy (Ilmu Faraidh).

${ }^{29}$ Nama aslinya Mohd. Shaghir Abdullah dan dikenal di Malaysia $\mathrm{Hj}$. Wan Mohd. Shaghir Abdullah sebagai penghimpun Khazanah Karya Pusaka Asia Tenggara, dulu mengajar di Sungai Bundung Kalimantan Barat. Ia adalah salah seorang murid H. Abdul Rani Mahmud. Menurut keterangan dari H. Abdul Rani, muridnya ini pernah meminjam dan membawa "manuskrip" Kitab Tasawwuf milik Abdul Rani ke Malaysia dan hingga saat ini belum dikembalikan. Setelah Abdul Rani meninggal Wan Shaghir pernah datang ke rumah almarhum untuk meminjam kembali kitabkitab "langka" lainnya, tetapi oleh keluarga beliau tidak diperkenankan.

${ }^{30}$ Ia menerima Tareqat Naqsyabandiyah

Mazhariyah dari tuan gurunya ini

${ }^{31}$ sejak tahun 1976 hingga wafat

${ }^{32}$ Wafat pada Hari Sabtu tanggal 24 April 1993, sebelumnya ada Ulama lain yang telah wafat mendahulinya yaitu gurunya, K. H. Ali Usman Ketapang wafat tgl. 30 Maret 1988. H. Ali Usman adalah seorang Ulama Besar yang terkemuka yang lama bermukim dan mengajar di Makkah. sebanding dengan ilmunya tampaknya belum ada. Daerah Kalimantan Barat merasa telah kehilangan seorang Ulama dan tokoh yang amat disegani dan dihormati.

\section{PENUTUP}

Berdasarkan informasi dan uraian di atas, ada beberapa hal yang dapat disimpulkan bahwa :

1. Terdapat sejumlah 10 (sepuluh) surau yang cukup terkenal di masa Kesultanan Pontianak. Surau-surau tersebut menjadi pusat pendidikan agama Islam pada masa itu. Kesepuluh surau tersebut berada di pinggir sungai Kapuas dan satu saja yang terletak di Parit Tok Kaya. Tiga surau berada di Kampung Kamboja dan satu surau berada di Kampung Melayu. Sedang di seberang satu wilayah dengan keraton Kadariyah Kesutanan Pontianak yaitu Tiga surau di Kampung Tambelan, satu surau di Kampung Sampit, dan satu lagi di Kampung Banjar Serasan/Segon.

2. Fungsi surau di Kesulthanan Pontianak berbeda dengan fungsi surau di Minangkabau atau daerah lainnya. Surau pada masa Kesultanan Pontianak digunakan hanya untuk tempat berbadah dan belajar ilmu agama Islam saja, tidak untuk tempat lainnya. Sedangkan di Minangkabau fungsi surau lebih komplek dan banyak.

3. Para Sulthan Kerajaan Pontianak memberikan hak otonom yang seluasluasnya kepada Tuan Guru untuk memberikan pendidikan agama Islam terutama di Surau-surau, bahkan beliau menerima siapa saja yang ingin mengajar meskipun dari negeri lain seperti dari Kelantan, Sarawak, Banjar dan menjadikan para Tuan Guru untuk memangku Jabatan di Kesultanan Pontianak.

4. Secara langsung maupun tidak langsung, telah terjalin jaringan Ulama 
Haramaiyn Timur Tengah diantara para Tuan Guru yang mengajar di Surau Kesultanan Pontianak. Baik Tuan Guru yang berasal dari Timur Tengah (Haramaiyin), Minangkabau, Pontianak, Banjarmasin, negeri Sarawak (Malaysia), negeri Kelantan (Malaysia), maupun negeri lainnya.

5. Materi yang diajarkan oleh Tuan Guru di Surau-surau amat bervariasi, mulai dari ilmu agama Islam ; seperti Ilmu Fiqh, Nahwu, sharaf, Qur;an, Tajwid, Qiraat dan sebagainya, hingga ilmu bela diri (ilmu gagah).

\section{DAFTAR PUSTAKA}

Andi, Tantra Nur, dkk., 2010. Pemerintahan Kota Pontianak dari Sultan sampai Walikota. Pontianak : Lentera Community.

Azra, Azyumardi, 2003. Surau : Pendidikan Islam Tradisional Dalam Transisi dan Modernisasi. Jakarta: Logos.

--------, 2012. Pendidikan Islam Tradisi dan Modernisasi di Tengah Tantangan Milenium III. Jakarta: Kencana.

Abdullah, Hawash, Perkembangan Ilmu Tasawuf dan Tokoh-Tokohnya di Nusantara, Surabaya : Al-Ikhlas, 1983.

Bruinessen, Martin Van, 1995. Kitab Kuning, Pesantren dan Tarekat. Jakarta: Mizan.

Mahmud, Abdul Rani, Kegiatan Ulama dan Fungsi Surau di Kalimantan Barat, Naskah Ketikan. Pontianak, 1982

--------, Riwayat Hidup, Pendidikan dan Pengalaman, Naskah Ketikan dan Tulis Tangan. Pontianak, 1984.

-------, Riwayat Hidup H. Muhammad H. Abdullah, Naskah Ketikan dan Tulis Tangan. Pontianak, 1986.
Penelitian Kelompok penulis pada PUSLIT IAIN Padang, 2010 A. Surau dalam Sejarah Pendidikan Islam di Minangkabau, diakses pada hari Senin tanggal 2 Juni 2014 di http://surautuo.blogspot.com/2011/03/sura u-melirik-aktifitas-transmisi.html 